\title{
LA EXCAVACIÓN DE TÚTUGI (GALERA, GRANADA) EN LAS CARTAS DE FEDERICO DE MOTOS Y EL MARQUÉS DE CERRALBO
}

\author{
THE EXCAVATION OF TÚTUGI (GALERA, GRANADA) IN THE LETTERS BETWEEN FEDERICO DE \\ MOTOS AND THE MARQUIS OF CERRALBO
}

\author{
CÁNDIDA MARTÍNEZ LÓPEZ \\ Universidad de Granada \\ candidam@ugr.es \\ http://orcid.org/0000-0002-4516-2025
}

Recepción: 31-05-2017

Aceptación: 11-10-2017

\section{Resumen}

Se analiza en este trabajo la correspondencia entre Federico de Motos y el marqués de Cerralbo en relación con la necrópolis de Tútugi (Galera, Granada). Estas cartas ofrecen una rica información sobre las condiciones en las que se realizó la excavación, sus fechas exactas, las dificultades y obstáculos cotidianos, sus primeras imágenes fotográficas y el valor dado por ambos al conocimiento del pasado y al patrimonio histórico. A través de ellas se observa también cómo circulaba la información sobre los descubrimientos arqueológicos; cómo funcionaron las redes y contactos entre quienes estaban cerca del territorio y los que habitaban las instituciones relacionadas con la Historia y la arqueología, o el papel que cada uno de los protagonistas tuvo en esta excavación. La base documental consta, básicamente, de las cartas e imágenes enviadas por Federico de Motos, localizadas todas ellas en el archivo del Museo de Cerralbo.

Palabras clave. Cultura ibérica; Tútugi; Galera; necrópolis; cartas; Federico de Motos; marqués de Cerralbo.

\begin{abstract}
This paper analyzes the correspondence between Federico de Motos and the Marquis of Cerralbo regarding the necropolis of Tútugi (Galera, Granada). These letters provide rich information on the conditions under which the excavation was carried out, as well as on the exact dates of the excavation, the difficulties and obstacles encountered in the daily work, the first photographic images, and how valuable was for the authors of the letters the knowledge of their past and historical heritage. These letters are also evidence of the information flow regarding archaeological discoveries, of how networks and contacts worked connecting the people close to the territory and those working in the fields of history and archaeology, and of the role each of them had in this excavation. The corpus consists mostly of letters and images sent by Federico de Motos, all of which are kept in the archive of the Cerralbo Museum.
\end{abstract}

Key words. Iberian culture; Tutugi; Galera; letters; Federico de Motos; Marquis of Cerralbo. 


\section{INTRODUCCIÓN}

La pasión despertada por la cultura ibérica en los medios arqueológicos y culturales de finales del siglo XIX e inicios del siglo XX nos acerca a uno de los yacimientos excavados en la segunda década del siglo XX, la necrópolis de Tútugi, y a dos de sus protagonistas, Federico de Motos, como agente directo de la excavación, y el marqués de Cerralbo en calidad de mecenas.

La correspondencia mantenida entre ambos arroja luz sobre las condiciones materiales, sociales y personales en las que se realizó la excavación y el alto valor que ambos personajes daban al descubrimiento y estudio de los yacimientos arqueológicos y del patrimonio histórico en el horizonte de una renovación cultural del país. Igualmente, pone de de relieve cómo se difundía la información sobre nuevos hallazgos y se formaban redes de comunicación e influencia entre quienes estaban cerca del territorio y quienes habitaban las instituciones relacionadas con la Historia, la arqueología y el patrimonio. Pero también habla de las cautelas sobre quien debía de dar la primicia de un nuevo yacimiento, o del papel diferenciado que cada uno los protagonistas tuvo en esta excavación. Incorpora, además, las primeras fotografías del yacimiento, lo que añade un valor singular por la rica información que proporcionan para el estudio de los mismos ${ }^{1}$.

Las cartas que se conservan se sitúan entre enero de 1914 y enero de 1919, período en el que se descubre y excava esta necrópolis. La base documental sobre la que hemos trabajado consta de 18 cartas de Federico de Motos al marqués de Cerralbo, y 15 fotografías con sus respectivas notas, localizadas todas ellas en el archivo del Museo de Cerralbo. No ha quedado constancia de las cartas que el marqués de Cerralbo envió a Federico de Motos, si bien en las que él escribe hay constantes alusiones a ellas. En el Archivo familiar de Motos $^{2}$ han quedado otras muchas, escritas entre otros por Breuil, Siret, Hugo Obermaier, Juan Cabré, etc., con los que Motos mantuvo relación (Martínez y Muñoz, 2011), pero no hay, por el momento, rastro de las que con certeza envió el marqués de Cerralbo. En cualquier caso las cartas de Motos constituyen un testimonio de primera mano para seguir la trayectoria de una excavación de la época, incluido el papel del

1. Algunas fotografías están algo borrosas o desenfocadas, pero es así como aparecen en los originales. Agradecemos al Museo Cerralbo su excelente disponibilidad para la consulta de las cartas y la reproducción de las fotografías y grabados que se incluyen en este texto.

2. Se trata de un archivo familiar privado. Aunque la mayor parte del Archivo documental de Federico de Motos desapareció a su muerte (Martínez y Muñoz, 2011), se han conservado cartas, fotografías, calcos y otros documentos de gran interés, bajo la custodia de uno de sus nietos. Agradecemos a Federico Motos Merlos que nos haya permitido el acceso al mismo. mecenazgo arqueológico, la evolución de la excavación o los intereses de los distintos personajes que pululaban en torno a estos yacimientos cuando saltaba la noticia de su existencia.

La enigmática belleza de las esculturas de los santuarios, la abundancia de vasos griegos e ibéricos, la arquitectura de las tumbas y sus lujosos ajuares o los debates sobre cronología y paralelos históricos llenaron páginas de revistas especializadas y de divulgación cultural y social. Por estas fechas los yacimientos y piezas arqueológicas ibéricas atraían a estudiosos españoles y extranjeros, aunque también a otras personas que veían en ellas una posibilidad de obtener beneficios económicos o rédito cultural. La espectacularidad de algunos de sus hallazgos y el que fuese considerada una cultura propia, aunque con profundas relaciones con el Mediterráneo, generaba un atractivo añadido para los investigadores y las instituciones españolas (Díaz-Andreu, 1997; Moret, 1998; Olmos, 1998; Blánquez y Roldán, 1999; Ruíz y Molinos, 2003; Pereira, Chapa, Madrigal, Uriarte y Mayoral, 2004; Ruiz, Bellón y Sánchez, 2006; González, 2012; González y Rueda, 2010; Aranegui, 2012). Una cultura nueva cuya investigación se vio afectada en sus inicios por las controversias sobre las capacidades de la arqueología española para dirigir la investigación de la cultura material de su pasado y la necesaria protección de un patrimonio histórico que venía sufriendo un constante expolio por la falta de instrumentos legales que lo impidiesen. El caso de la Dama de Elche y su exposición en París, causó un importante impacto en la España de la época (Ramos, 2003; León, 1996; 1998).

Era evidente que una cultura de esas características necesitaba ser conocida y estudiada, y las informaciones que llegaban desde los distintos territorios se convertían en un bien precioso para aquellos que estaban al frente de las instituciones oficiales de la historia y la arqueología. Pero también la naturaleza de los hallazgos, sobre todo los vasos griegos, esculturas o la joyería, convirtieron estas piezas en objeto de deseo de los coleccionistas, que desplegaron todos sus tentáculos para llegar antes que los arqueólogos y hacerse con el preciado botín. Como bien señalan Cabré y Motos (1920) en relación con la necrópolis de Tútugi, la pobreza y la incultura de las gentes del lugar que expoliaban las tumbas fueron excelentes aliadas de estos coleccionistas de alto vuelo, que animaron con sus compras el saqueo de los yacimientos antes de que llegasen los arqueólogos o incluso en plena fase de excavación.

En la historia de este yacimiento (Pereira, Chapa, Madrigal, Uriarte y Mayoral, 2004) se dan cita, pues, la pasión por la arqueología de Federico de Motos y el valor dado a la misma por el marqués de Cerralbo; las malas condiciones económicas de la zona y el interés de los ricos coleccionistas; el interés despertado en la prensa cultural y el abandono y escasez de medios para llevar a cabo las excavaciones y proteger el patrimonio. Toda una radiografía de esa España que 
se debatía entre el anclaje al pasado y los horizontes de modernidad que buscaban con ahínco las corrientes más ilustradas.

La necrópolis de Galera ha sido objeto de estudios de gran valor en las últimas décadas, como el publicado por el Ministerio de Cultura (Pereira, Chapa, Madrigal, Uriarte y Mayoral, 2004) en el que participan destacados especialistas, o los trabajos de Rodríguez Ariza $(2008,2014)$ que ponen en valor la potencialidad actual del yacimiento. Con todo, las cartas de Motos al marqués de Cerralbo han permanecido inéditas y su análisis ofrece información tanto sobre los pormenores de su excavación como sobre el funcionamiento de las redes entre los distintos personajes que se movían en torno a la arqueología de ese momento.

\section{LOS PROTAGONISTAS: FEDERICO DE MO- TOS Y EL MARQUÉS DE CERRALBO}

Los protagonistas de esta correspondencia ocupan un papel distinto en la trama o red arqueológica de la España de la segunda década del siglo XX. Federico de Motos, farmacéutico y arqueólogo de vocación, se sitúa en la periferia de la red y en contacto directo con el territorio donde se estaban descubriendo los yacimientos. Él pudo incorporarse a la misma a través de sus contactos y trabajos con personalidades relevantes de ese momento como Breuil, Siret, Obermaier o Hernández Pacheco. El marqués de Cerralbo, personalidad polifacética y de gran influencia en los medios políticos y culturales, con una buena posición económica, se situaba en el centro de la red, en el lugar donde se tomaban las decisiones y podía ejercer un cierto mecenazgo.

No cabe duda de que, como en cualquier trama, todos los personajes tienen un papel diferenciado, cumplen una función y crean unas relaciones de interés mutuo que permiten alcanzar objetivos comunes. Detengámonos brevemente en cada uno de estos protagonistas para entender mejor sus intereses y expectativas.

La vocación arqueológica de Federico de Motos (Vélez Blanco, Almería, 1865-1931) es fruto de su época, del contexto universitario en el que se formó y de su relación con los ambientes que hacían de la cultura y del patrimonio una de las bandera de la regeneración y avance de España (Fig.1). Estudió Farmacia en la Universidad de Granada y los estudios de Doctorado en la Universidad Central de Madrid. En Granada simultaneó los estudios de Farmacia con los de Bellas Artes en la Escuela de Artes, lo que le permitió introducirse en un ambiente donde se seguían con interés los descubrimientos arqueológicos y los debates sobre la protección del patrimonio, de la mano de Manuel Gómez Moreno o Francisco de Góngora. (Martínez y Muñoz, 2011).

$\mathrm{Su}$ otra ciudad de referencia fue Madrid, a donde viajaba con asiduidad. El Madrid que frecuentó Federico de Motos fue el del Museo Nacional de Ciencias

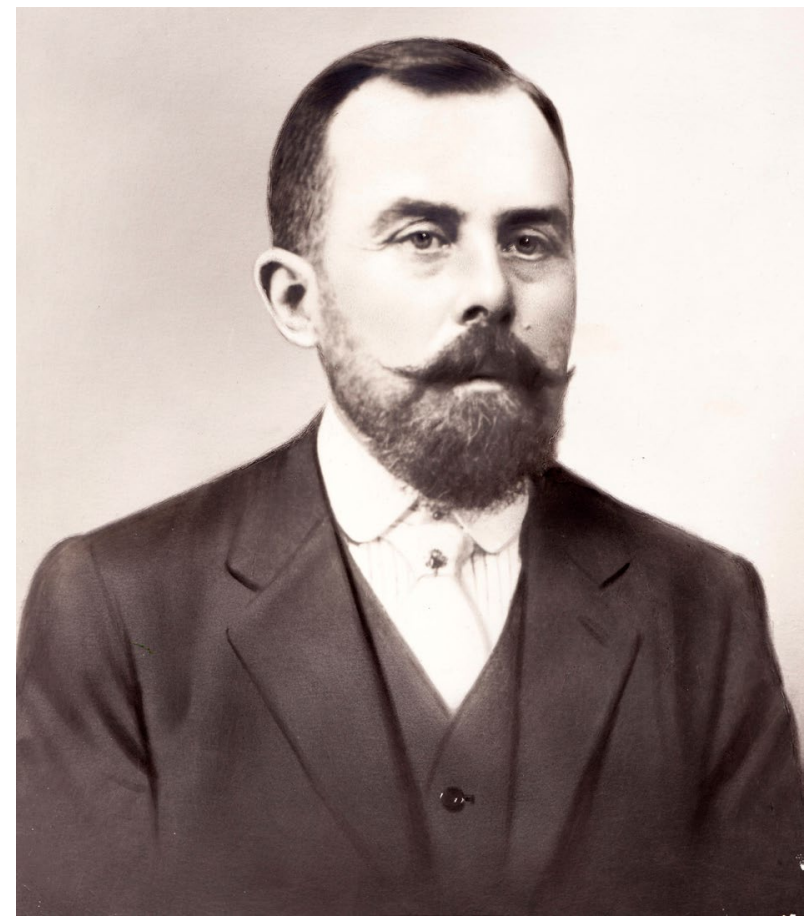

Figura 1: Federico de Motos. Biblioteca Municipal de Vélez Blanco.

Naturales y la Junta Superior de Excavaciones, el del Museo Arqueológico Nacional y la Real Academia de la Historia, el de las tertulias del Casino y del Ateneo. Eduardo Hernández Pacheco, el marqués de Cerralbo, Hugo Obermaier, Juan Cabré, Fidel Fita, José Ramón Mélida o Ignacio Bolívar, entre otras personalidades del mundo de la arqueología, la paleontología y la historia, recibieron sus visitas para hablar de sus hallazgos y proyectos, de sus publicaciones y colecciones arqueológicas. La correspondencia que con ellos mantuvo es buen exponente de respeto, reconocimiento y amistad mutuos ${ }^{3}$.

La temprana dedicación de Federico de Motos a la arqueología se produce en un tiempo marcado por profundos cambios y controversias en la concepción de la prehistoria, la historia y sus métodos de análisis. Participó de un discurso donde se mezclaban los sentimientos de frustración por el expolio del patrimonio, la rebeldía personal para contrarrestar la destrucción del mismo y la satisfacción de contribuir a conocer y recuperar un pasado que debía de ayudar a conformar la identidad colectiva como país. Colaboró con sus estudios al esfuerzo de muchos intelectuales españoles, ligados al Institucionismo, por crear una ciencia española, en particular una escuela arqueológica propia sin la tutela de los europeos que la habían acaparado en gran medida. Pero siempre mantuvo la deferencia y el reconocimiento hacia dos de sus grandes maestros,

3. El Archivo familiar guarda esa rica correspondencia, sobre todo desde 1911 hasta 1922 (Véase, Martínez y Muñoz, 2011). 
que eran precisamente extranjeros: Breuil y Siret (Martínez, 2015)

Cuando Federico de Motos entró en contacto de forma activa con el mundo ibérico estaba en plena madurez vital y arqueológica. Su trayectoria históricoarqueológica contaba con más de una década dedicada al descubrimiento y estudio de las pinturas rupestres y las culturas del final del neolítico del norte de Almería y sureste peninsular. La cultura ibérica no podía quedar fuera de su ámbito de estudio. Así lo afirmaba Henri Breuil, con quien había colaborado estrechamente, en una carta en la que dice comprender su dedicación a los asuntos ibéricos por la riqueza arqueológica y artística de los yacimientos:

Veo que usted sigue dedicándose más y más a asuntos ibéricos, y lo comprendo, por la riqueza arqueológica y artística de tales yacimientos y por las particularidades que esta época presenta en su provincia. Tendré mucho gusto saber a menudo de los hallazgos de usted. (Carta de Breuil a Motos, 14 -1 1920. Archivo Motos)

Aunque, como veremos más adelante, la necrópolis de Galera no fue su primer acercamiento a la cultura ibérica, sí podemos afirmar que fue el yacimiento al que dedicó más tiempo y esfuerzo, además de verse culminado con la publicación de la Memoria correspondiente junto a Juan Cabré. Federico de Motos obtuvo el permiso oficial para la excavación de Galera en julio de 1917 y llevó a cabo la primera parte de la misma con el patrocinio económico del marqués de Cerralbo. ¿Qué relación tenían para que Cerralbo se convirtiese en el mecenas de la excavación?

El marqués de Cerralbo (1875-1922), personalidad polifacética, con una larga trayectoria política en el carlismo, una intensa dedicación a la vida cultural y orientada parte de su vida a la arqueología tanto en excavaciones directas como en calidad de conferenciante o de autor de publicaciones, ocupa el centro de la red arqueológica del momento (Jiménez Sanz, 1996; Navascués, 2007; Granados, 2012; Fernández Escudero, 2015). De todas las facetas de su itinerario vital destacamos sólo su dedicación a la arqueología y, sobre todo, su influyente posición en los distintos organismos relacionados con la Historia y la arqueología.

Su actividad arqueológica se centró en Guadalajara, Zaragoza, Soria y Segovia, donde realizó unas 180 intervenciones (Navascués, Conde y Jiménez, 1998) con publicaciones sobre el Alto Jalón (1909), las necrópolis ibéricas (1916), etc. Su posición económica le permitió convertirse en un gran coleccionista de arte, tanto de pintura, escultura, como de piezas arqueológicas (Alvar, 2007) le que le otorgaba prestigio y reconocimiento dentro del mundo cultural de la época. Tras la aprobación de la «Ley sobre excavaciones artísticas y científicas y de conservación de ruinas y antigüedades», en la que participó como miembro del Senado (Fernández Escudero, 2015) se incorpora activamente a los organismos donde se tomaban decisiones sobre los yacimientos. En 1913 era nombrado vicepresidente de la Junta Superior de Excavaciones y Antigüedades, académico de número de la Real Academia de la Historia y, bajo su dirección se constituye la Comisión de Investigaciones Paleontológicas y Prehistóricas. Son estos unos años de intensa actividad, y su correspondencia con las personalidades del mundo de la arqueología y la cultura le ayuda a mantenerse informado de lo que acontece en cada momento (Abascal, 2006). Por su casa pasan los principales arqueólogos del momento con los que establece una intensa relación (las cartas de Federico de Motos hacen alusión a esas visitas) en la que, sin duda ocupa una posición de privilegio e influencia.

En este contexto no es de extrañar que, por su capacidad económica, su influyente posición y el valor que le daba a la historia y patrimonio de su patria, ejerciese un mecenazgo que contribuyó a la excavación y estudio de algunos yacimientos como es el caso del que nos ocupa, la necrópolis de Galera. Las cartas que aquí analizamos ponen de relieve no sólo el dinero que aportó para esta excavación sino el seguimiento de la misma, preocupándose de cuestiones cotidianas como cuando se puede o debe excavar, debido a la climatología, hasta cómo están saliendo a la luz pública, a través de la prensa, los materiales de esos yacimientos.

Dos personalidades diferentes, y en distinto lugar y posición, unidos por un interés común, la arqueología y el papel relevante que debía de cumplir en la cultura y la ciencia española de los comienzos del siglo XX.

\section{LAS PRIMERAS CARTAS SOBRE NUEVOS YACIMIENTOS IBÉRICOS: MINATEDA}

Las primeras cartas conocidas sitúan a Motos como uno de los arqueólogos que informan a Cerralbo de los descubrimientos que va realizando, sean sobre abrigos con pinturas rupestres, estaciones neolíticas o relacionadas con la cultura ibérica en el sureste peninsular.

De hecho la primera información relativa a esta cultura no fue la de la necrópolis de Galera, sino la de Minateda (Hellín, Albacete), de la que le dio cumplida información a lo largo de 1915 tanto de la conocida cueva con pinturas rupestres como de la necrópolis ibérica:

No sé si por el Abbé Breuil habrá V.E tenido conocimiento de la última excursión reciente que hemos hecho, y de lo fructuosa que fue, y si así no fue me veo obligado a comunicárselo. En primer lugar fue muy de su agrado los sitios con pinturas rupestres que le tenía buscados, en particular un abrigo cuyo frente tiene diez y seis metros de pinturas donde hay más de quinientas figuras, en las que no sólo está muy bien representada la especie humana sino que el reino animal lo tiene admirable, siendo todas de un realismo sorprendente; abundan mucho los ciervos y cabras en diversas actitudes, el caballo, el toro algunas veces y un magnífico rinoceronte? 


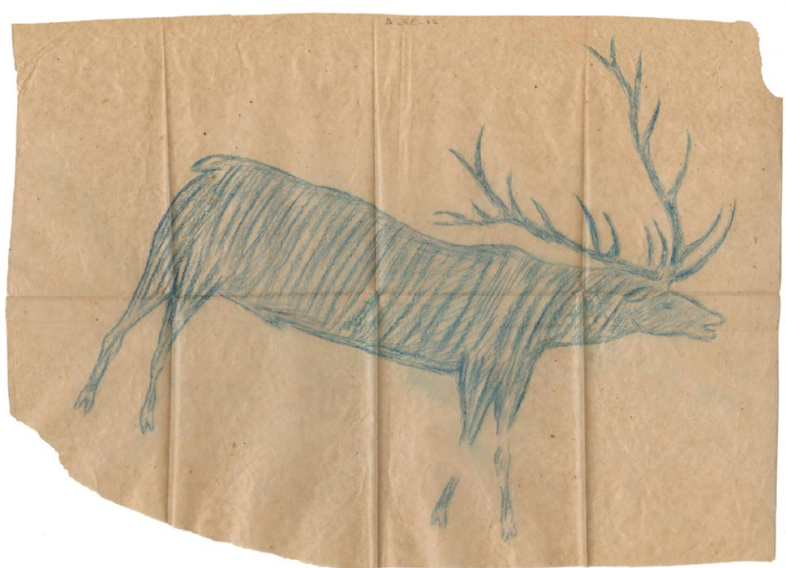

Figura 2: Calco de un ciervo de la Cueva de Minateda realizado por Motos. Museo Cerralbo.

En las figuras humanas se ven grupos magníficos como son uno en que varios hombres con cascos persiguen a otros que corren, siendo de notar que éstos son de menor tamaño; resulta también muy interesante un grupo formado por una mujer que lleva de la mano un niño, a esto hay que añadirle lo bien conservado y todo de un realismo artístico notable. Mando a V. E. como muestra un ciervo que sigue a otros y que por su actitud parece que está bramando. Hice este calco expresamente con ánimo de remitírselo.

A más tengo el gusto de notificarle como he tenido la suerte de encontrar el lugar en que existió una gran población ibérica, y después de buscar con insistencia encontré también la necrópolis en donde he hecho excavaciones logrando encontrar bastantes sepulturas de incineración cuyos huesos quemados fueron depositados en urnas de barro pintadas y con sus tapaderas; en algunas encontré fíbulas, brazaletes o algún pendiente de cobre muy destrozado por la acción del fuego. En los hoyos de cremación he encontrado sables de hierro, una lanza, fíbulas y pesas de barro, habiendo recogido una buena colección de trozos de urnas y jarrones con pinturas en rojo muy interesantes. Supongo que en este sitio y haciendo más excavaciones pudieran encontrarse cosas muy notables que aportarán muchos datos para la arqueología; yo tengo notas tomadas en el terreno y apuntes de este descubrimiento que mandaré al Sr. H. Pacheco. (Carta de Motos a Cerralbo, 12-5-1915, Museo Cerralbo (M.C.) 21-37).

Cerralbo tuvo, pues, información temprana sobre la cueva de la Minateda y del poblado y necrópolis ibéricos gracias a las cartas de Motos, aunque, al parecer no fueron consideradas de su interés.

Las circunstancias del hallazgo de la necrópolis del Tolmo de la Minateda figuran en un informe manuscrito que envió a H. Pacheco y a la Real Academia de la Historia por «si los considera de interés se le conceda ver y coordinar las excavaciones $\rangle^{4}$. La

4. Nota manuscrita del autor, localizada en el archivo familiar. Aunque está dirigida A la Real Academia de la Historia, no primera excavación la llevaron a cabo Motos y Breuil, y aunque Motos buscó la financiación de la misma, presumiblemente, no consiguió la cantidad necesaria para continuarla. El informe que dirige a Eduardo Hernández Pacheco lleva fecha de abril de 1916, casi un año después, y la noticia de sus descubrimientos circuló por el ambiente arqueológico de la época. De hecho tenemos constancia de la presencia de Motos en Madrid en esa misma fecha y de la visita que hace a Fidel Fita, acompañado por Juan Cabré, para llevarle el calco de una inscripción romana encontrada cerca de Hellín ${ }^{5}$.

También la Revista de Archivos Bibliotecas y Museos publicaba en 1918 un artículo sobre el poblado ibérico del Tolmo de la Minateda. En él hay dos alusiones de interés. La primera, que dicha aportación era fruto de una excursión que habían hecho a dicho poblado el autor, Obermaier y Wernert, y la segunda es la mención expresa a Federico de Motos como descubridor del yacimiento y el reconocimiento a su desvelo por el estudio de la riqueza arqueológica:

No hemos de apropiarnos el nombre de descubridores de la estación, pero sí de modestos editores de la importante localidad, porque no nos cuadra. Porque el verdadero descubridor es don Federico de Motos (de Vélez Blanco), el cual ha descubierto y excavado parcialmente el cementerio, encontrando algunos restos de cerámica de suma importancia; hemos podido ver la citada cerámica gracias a la liberalidad de mis amigos: uno el jefe del Laboratorio de Prehistoria, señor Hernández Pacheco, y otro, el profesor de dicho centro, el doctor Obermaier.

Nos congratulamos de citar en esta modesta nota al señor Motos, que tanto se desvela por el estudio de la riqueza prehistórica de la región. (Varela, 1918)

Motos llevó a cabo excavaciones en la necrópolis, de la que guardó sus notas y materiales, pero no tuvo continuidad (López y Sala, 1989). Tal vez tuviese que ver con no haber conseguido los recursos económicos para hacerlo, o por estar prospectando otros espacios. En cualquier caso sigue informando a Cerralbo de sus actividades, con la esperanza de lograr el apoyo necesario:

He recibido su atenta con algún retraso y enterado de su próximo viaje a Sevilla, lo siento por privarme del honor que hubiera tenido en visitarle en mi inmediato viaje a esa habiéndole puesto en antecedentes de cosas muy importantes referentes a arqueología

tenemos constancia de su existencia en la citada Institución. También al inicio indica que ha sido «mandado el 10 de abril E. Pacheco». En esas mismas notas menciona el primer descubrimiento que habían realizado, el de la Cueva de la Minateda, sobre la que se reserva dar detalles por estar siendo estudiada por el Abate Breuil. Archivo Motos.

5. Carta de Federico de Motos a Fidel Fita, de 2 de noviembre de 1916. CAAL/9/7944/24(1). 
que no pueden confiarse a una carta, y que para la exposición de Sevilla también vendría como anillo al dedo. A su vez le hubiera mostrado fotografías $\mathrm{y}$ calcos (que estoy terminando) de los objetos de más interés que he encontrado, y con los datos necesarios que tengo del lugar de la necrópolis, con la valiosa ayuda de V.E. hubiésemos hecho el anuncio, habiendo a su vez convenido si lo estimaba oportuno el viaje del Sr. Cabré al sitio para si en vista de su informe se acordaba empezar las excavaciones. (Carta de Motos, 16-4-1916, M.C. 21-165)

Pero las noticias y primeras prospecciones en Galera (Granada), que ofrecía un conjunto arqueológico de considerables dimensiones y gran riqueza material, le llevó a orientar sus trabajos hacia ese lugar hasta la publicación de la Memoria de la excavación en 1920.

\section{PRIMERA FASE DE LA EXCAVACIÓN DE LA NECRÓPOLIS DE TÚTUGI EN 1917. EL MECE- NAZGO DE CERRALBO Y LOS INFORMES DE MOTOS}

El primer contacto de Federico de Motos con esta necrópolis se produjo de forma similar a la de Minateda, junto a Henri Breuil. La noticia sobre los restos arqueológicos que estaban apareciendo en Galera llegó a sus oídos en agosto de 1916 cuando visitaban una cueva con pinturas rupestres en el municipio de Huéscar (Granada). Las circunstancias de esta primera visita a Galera las relata en un informe que envió a Fidel Fita el 13 de febrero de 1917 y que se conserva en la Real Academia de la Historia:

En el mes de agosto último en ocasión de hallarme acompañando al sabio arqueólogo Mr. Breuil haciendo estudios en unas cuevas con pintura de arte rupestre situadas en las estribaciones de la sierra llamada la "Sagra» del término de Huescar, inmediato a Galera, llegó a nuestro conocimiento una noticia en extremo curiosa que se comentaba con verdadero entusiasmo por aquellas inmediaciones. Nos refirieron que en la próxima villa de Galera unos labriegos, influenciados por el relato que les hiciera una joven pariente de ellos respecto a sus sueños, la que en sus alucinaciones vio ricos tesoros consistentes en grandes arcones repletos de monedas de oro y plata no faltando barras de tan codiciado metal; en otras se encontraban ricas alhajas y hasta armas... ¡Cual no sería su sorpresa cuando a las pocas horas de comenzado el trabajo empezaron a parecer las señales del codiciado tesoro. Consistían éstos en grandes sillares, pedazos de columna, algún capital y trozos de cerámica. (RAH, CAGR, 9/7955/62)

Animado por la riqueza de los materiales encontrados $\mathrm{y}$, sobre todo, por la cerámica ibérica que había visto en otros lugares cercanos al cerro de El Real, Federico de Motos volvió unos meses después localizando la necrópolis:
Como entre los escombros hallara trozos de cerámica ibérica pintada, avivó más mi curiosidad investigadora, haciendo que volviera de nuevo al sitio, y con más detenimiento a hacer un estudio más minucioso de esta comarca, teniendo la satisfacción de haber determinado con exactitud el lugar de la necrópolis ibérica en extremo notable; excavando algunas sepulturas en las que encontré ajuares funerarios interesantísimos; con estos datos suspendí los trabajos hasta obtener la debida autorización ${ }^{6}$.

Como venía siendo habitual comunicó la importancia de su hallazgo al marqués de Cerralbo:

En mi anterior olvidé de incluir entre mis descubrimientos dos ánforas grandes, todas ellas pintadas de rojo, con fajas de meandros y grecas bastante bonitas; estas ánforas están muy incrustadas con una capa caliza que impide poder apreciar bien la pintura en conjunto, apreciándose sólo por algunos sitios; desde luego se nota una influencia griega muy marcada, teniendo a mi juicio una fecha igual a la necrópolis de la Minateda, donde encontré espadas falcatas y la pintura de algunas de las urnas son muy semejantes; la diferencia que al pronto se nota es que las gentes de por aquí tenían mejor posición. (Carta de Motos, (1-4-1917, M.C. 21-264)

En este caso Motos logró financiación para la misma. Cerralbo, a la vista de los informes que éste le proporciona sobre la riqueza material del yacimiento, decidió financiar la excavación que, en consonancia con los nuevos tiempos, debía de contar con la autorización oficial.

Le agradezco infinito su sincera felicitación por mis últimos descubrimientos, aceptando desde luego el parecer de usted con respecto a este asunto. Como ignoraba los requisitos necesarios para pedir la autorización para hacer las excavaciones, tengo que ir de nuevo al sitio a tomar los antecedentes necesarios, y una vez que los tenga los remitiré a V.E o bien iría por ahí, creyendo que esto último sea lo más conveniente para formar juicio más exacto tanto por el relato que haga, cuanto por el examen de algunos objetos y fotografías que procuraré llevar, y en el caso de acordar dar principio de inmediato a las excavaciones, desde esa nos trasladaríamos al sitio en unión del amigo Cabré que según me escribió estaba designado para acompañarme en este trabajo. (Carta de Motos, 1-4-1917, M.C. 21-235)

La solicitud hecha por Motos fue atendida, autorizándole oficialmente a excavar en el Cortijo de San Gregorio, el Cerro de El Real y el Cerro de San Cristóbal

6. Heraldo de los Vélez, setiembre 1917. Un texto muy similar, bajo el título "Los descubrimientos de Galera», escrito igualmente por Federico de Motos, se recoge en La Alhambra. Revista quincenal de Artes y letras, 15 de noviembre de 1917, pp. 483-486. 

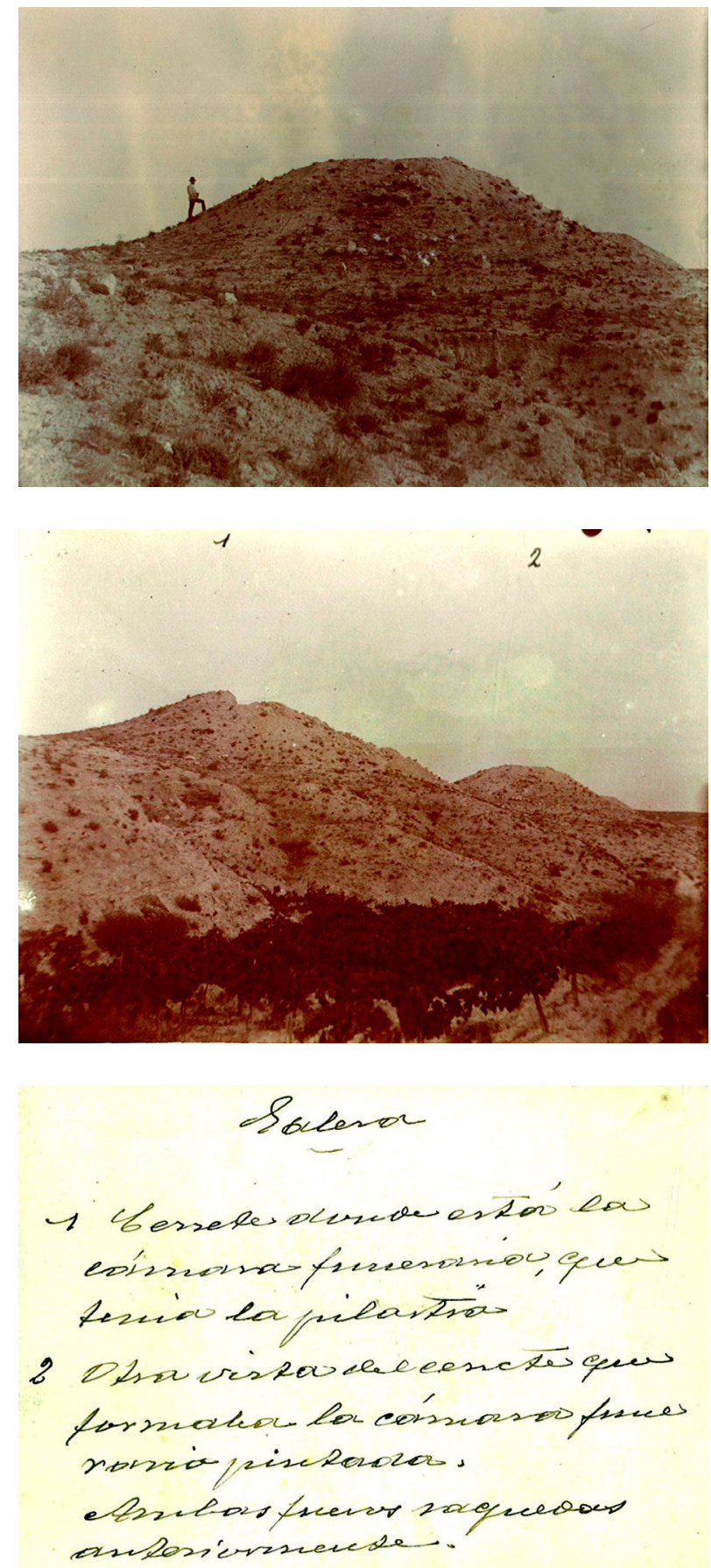

Figuras 3, 4 y 5: Túmulos de la necrópolis de Tútugi. En el reverso nota manuscrita: 1. «Cerrete donde está la cámara funeraria que tenía la pilastra. 2. Otra vista del cerrete que formaba la cámara funeraria pintada. Ambas fueron saqueadas anteriormente». Fotografía y notas de Federico de Motos. Museo Cerralbo.

por Real Orden de 8 de mayo de 1917. Comenzó la campaña en junio, extendiéndose a algunos meses de otoño. A lo largo de ese tiempo Cerralbo, como patrocinador económico, tuvo cumplida información del avance de la excavación, de los materiales encontrados, de las características de las tumbas, del terreno en el que se hallaban, etc. El tipo de información que le proporciona Motos suele ser detallada tanto sobre los hallazgos, que suele describir con detalle, como sobre las dificultades que se va encontrando:

Hace bastantes días que me encuentro en este pueblo practicando las excavaciones que prometí; no he escrito antes a V.E hasta darle alguna noticia satisfactoria respecto a éxitos obtenidos, y ya que por fin encontré algo de interés me apresuro a comunicárselo. Como de más interés le pongo en conocimiento del hallazgo de una urna cineraria hecha en piedra de forma y tamaño parecido a la que tuve el honor de enseñarle, pero esta no está rota, únicamente la tapa está fraccionada en dos o tres trozos fácil de unir; está decorada con una franja pintada en rojo, de buen gusto y muy típica; estaba llena de huesos quemados y entre ellos encontré unos pequeños pendientes de oro; en la misma sepultura había otra urna de barro llena igualmente de huesos pero sin alhajas; la tapadera de la urna tiene para cogerla, tallada la flor simbólica que aparece en las pinturas, y la que decoraba la urna que encontré antes.

Otra sepultura también de interés contenía una urna de barro pintada llena de huesos quemados, al lado había una lanza, una falcata, el freno de un caballo, éste muy destruido efecto de ser el terreno muy salitroso y atacar el hierro mucho... (Carta de 8 de junio de 1917. Museo Cerralbo, 21-262)

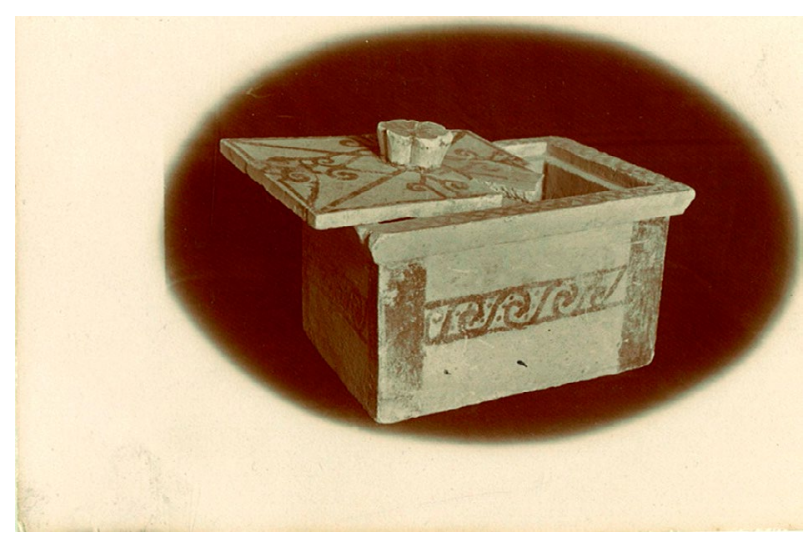

\section{CARTE POSTALE}

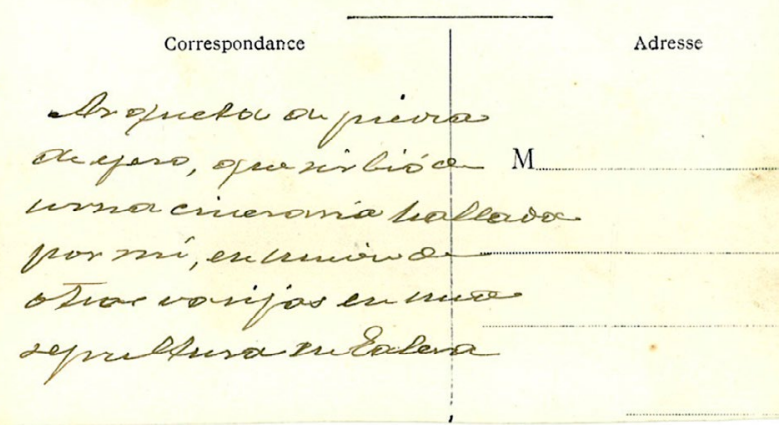

Figuras 6 y 7: Arqueta ibérica. En el reverso nota manuscrita: "Arqueta de piedra de yeso que sirvió de urna cineraria, hallada por mi en unión de otras vasijas en una sepultura de Galera». Fotografía y notas de Federico de Motos. Museo Cerralbo. 
El tenor de las cartas escritas durante todo el mes de junio es similar, siendo una fuente excelente para conocer el ritmo de la excavación, los hallazgos y todas las vicisitudes que rodearon la intervención:

..... he encontrado otras sepulturas de interés por el ajuar funerario que contenían; en una de un guerrero hallé dos dardos grandes de hierro de los llamados soliferrum y tres pequeños cuya longitud es de poco más de $30 \mathrm{cms}$., por un extremo terminan en punta y por el opuesto en pequeña lanza de forma de hoja de sauce; a más tenía esta sepultura una urna de barro pintada bastante buena..... En otra, en cuya cámara en el centro había un hoyo pequeño cuadrangular revestido de yeso donde estaban los huesos quemados y todo cubierto con una losa, encontré un pendiente de oro en forma de racimo de uva y botones de oro pequeños y que supongo restos de otro pendiente fundido efecto del fuego intenso al quemar el cadáver... (Carta de 26 de junio de 1917. Museo Cerralbo, 21-263)

Motos mantuvo informado a Cerralbo de las fechas que está en Galera, del descanso del verano, debido al calor que hace en esa zona, y de cuando reanuda la excavación. A su vuelta a Galera, a finales de setiembre y a lo largo de octubre, continúa sus detallados informes sobre las excavaciones con descripciones sobre algunas de las tumbas más conocidas de esta necrópolis. Ya hacia el final de su estancia en Galera, y en una de sus cartas (3-11-1917), hace un interesante balance de lo que ha descubierto en el mes de trabajo realizado:

Esta segunda campaña fue también bastante fructuosa en hallazgos, pues a pesar de que sufrí una verdadera decepción con la sepultura que más interés tenía o sea la que tuve que solicitar permiso de D. Joaquín Fernández, la que por su tamaño y esmerada construcción supuse contenía un rico ajuar funerario, resultó que después de una esmerada y larga excavación y de haber perdido una bonita moneda que llevaba de dije (todo se conjuró) no contenía nada en absoluto, por lo que supongo que tanto esta sepultura como todas las del mismo tipo que van excavadas fueron saqueadas en tiempos antiguos, por estar muy visibles, pero al menos no se perdió del todo el tiempo, tomé nota del tamaño, orientación y construcción pudiendo apreciar que el corredor de entrada estuvo pintado de rojo, sacando las fotografías que acompaño, con esta señal por la espalda.

Otra sepultura de poca importancia al parecer nos indemnizó bien del trabajo prestado, encontrando en ella una hermosa copa griega con su plato, que, aunque rota y aplastada por hundimientos, pude recoger todos los pedazos y unirlos, quedando bastante bien, como V.E. puede ver en la fotografía $\mathrm{n}^{\circ} 2$, siendo la escena que representan las figuras que la decoran muy bonita y de interés, por otro lado es completamente igual a la otra cuya fotografía le mandé o sean las tres figuras con manto largo.

A más contenía una urna lisa con tapadera y una vasija rota cuya forma es igual a la urna de los guerreros, ésta toda pintada de rojo y llena de huesos quemados y en la urna con los huesos una fusaiola,
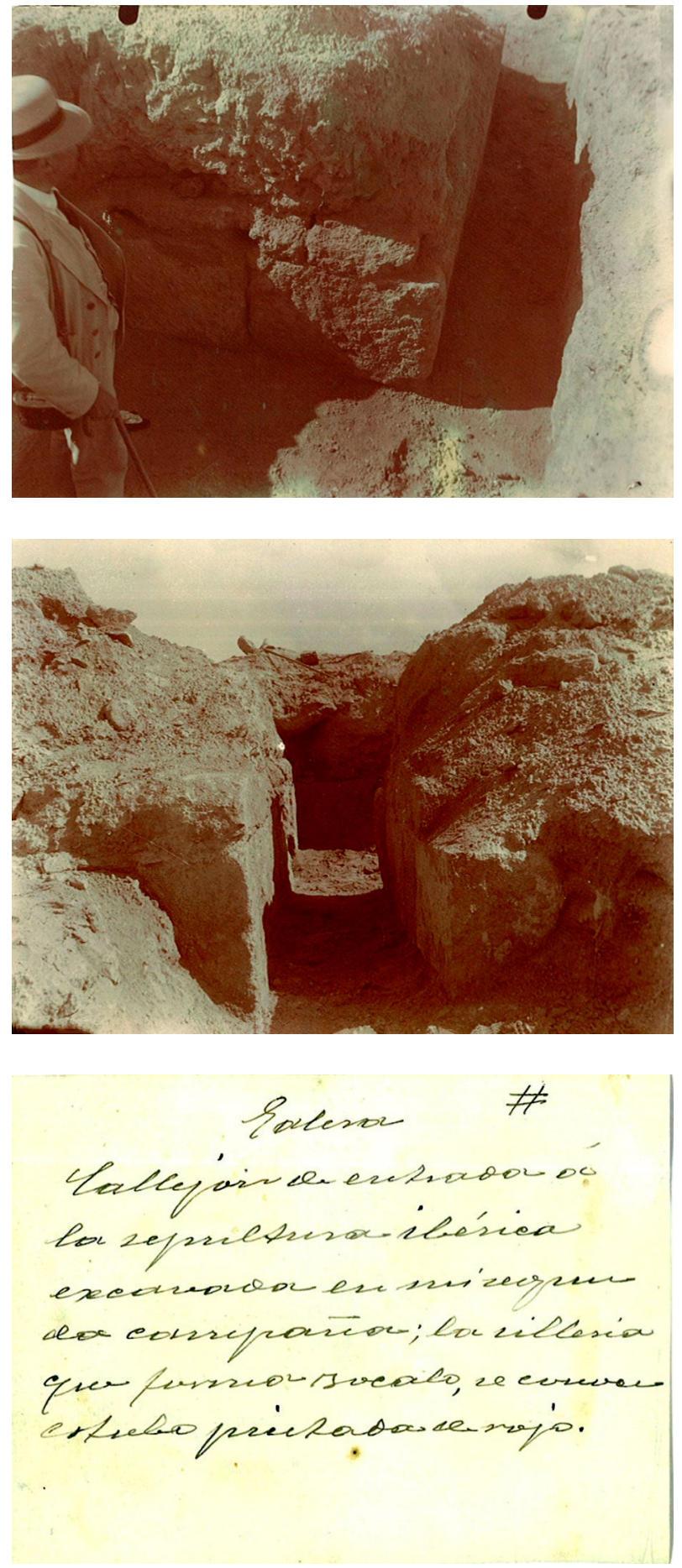

Figuras 8, 9 y 10: Imagen del corredor de una de las tumbas de Tútugi. En el reverso nota manuscrita: "Callejón de entrada a la sepultura ibérica excavada en mi segunda campaña; la sillería que forma zócalo, se conoce estuvo pintada de rojo». Fotografía y notas de Federico de Motos. Museo Cerralbo.

una falcata en dos trozos, una lanza larga y estrecha y dos más pequeñas con trozos de hierro que supongo dardos, trozos de metal muy rotos que creo placa de cinturón y todo muy oxidado por.... haber sufrido un fuego intenso.

Federico de Motos no se contentaba con el hallazgo de las tumbas y objetos. También lo vemos interesado en 
el análisis de las sustancias que aparecen en las tumbas, en la creencia de que pueden ofrecer información sobre otras vertientes de la vida de la población ibérica y de sus rituales. Como buen farmacéutico y hombre de ciencias le preocupaba la composición de ciertas sustancias $\mathrm{y}$, ante la duda sobre su composición, le pide a Cerralbo que busque el modo de analizarlas:

\begin{abstract}
...en una de mis anteriores decía a V.E que me indicara cuando sería tiempo oportuno para mandarle muestras de una sustancia encontrada junto a las sepulturas que supongo era harina, para que las analizaran como también unos huesos encontrados recubiertos de una especie de líquido que parece fieltro, y que para hacer mención a ello convendría saber ciertamente de lo que se trata; también mandaría muestras de una clase de arenisca de que está completamente rellena una cueva puestas allí con algunos objetos, que pudiera aclarar un análisis, como este es un tiempo en que mucha gente se ausenta es por lo que hago a V.E esta indicación.. (Carta de 13 de julio de 1917. M. C., 21-257)
\end{abstract}

\section{EL COSTE DE LA EXCAVACIÓN}

El marqués de Cerralbo entregó a Federico de Motos 500 pesetas para hacer esta campaña de 1917, tal como sabemos por el informe que, a mitad de campaña, hizo sobre los gastos realizados. En el mes de setiembre le envió una nota detallada sobre el empleo de los fondos hasta finales de junio, que estuvieron dedicados, exclusivamente, a pagar al personal que contrató, corriendo todo lo demás a su cargo. Entre los trabajadores que acompañaron a Federico de Motos tres procedían de Vélez Blanco y habían estado con él en otros yacimientos por lo cual tenían cierta experiencia en este tipo de actividades. Los demás eran de Galera.

La nota que reproducimos, adjunta a una de sus cartas, no sólo da cumplida información sobre la gestión del dinero confiado sino del salario diario que se pagaba a un jornalero por trabajar en estos yacimientos, notándose la presencia de menores en el mismo.

\footnotetext{
...Remito a V.E una nota de los gastos que hasta la fecha llevo hechos; he procurado hacer la cosa lo más económicamente que he podido con objeto de sacar el mejor partido al capital que me confió; con el resto llegaré donde pueda y con el resultado lo tendré en antecedentes.

(Nota adjunta)

Sr. Motos

Gastos hechos hasta el último día de Junio de 1917 en las excavaciones de Galera y Orce

Tres jornaleros de Vélez Blanco que se llaman Manuel Galindo Valera, Juan Rico y Manuel Galindo, hijos de éste; los dos primeros han ganado a tres pesetas el jornal y el último por ser menor a 2,50.

Echaron 25 días a 8,50 los tres por día importa 212,50

Dos días para transporte de Vélez Blanco a Galera y viceversa 17
}

Dos jornaleros de Galera, llamados Clemente Aránega y Salvador M, a 3 pesetas cada uno, echaron 19 días de trabajo, importan 114.

Total 343,50

Diferencia a 500 que recibí, 156,50

(Carta de 16 de setiembre de 1917. Museo Cerralbo, 21-235)

Es evidente que con 156 pesetas que le restaban, la campaña de otoño debió de contar con menos operarios, menos días o correr a cargo completamente del propio Federico de Motos.

Como era habitual cuando la excavación se hacía con fondos particulares, los materiales hallados quedaban en manos de las personas que la habian financiado. Por ello Cerralbo recibió una parte de los objetos encontrados en Tútugi por Motos, aquellos que él le indicó como queda atestiguado en una de las cartas: «Al propio tiempo me indica los objetos que juzgue necesarios que he de llevar para tenerlos preparados, llevando algunos que le tengo reservados como sorpresa» (28-XI- 917, M.C. 21-260). Estos materiales formaron parte de la colección de Cerralbo a la que se hace mención en la memoria publicada en 1920.

\section{NOTAS DE CAMPO Y FOTOGRAFÍAS. PRE- PARAR LA MEMORIA}

Federico de Motos, que ya había excavado el cerro de las Canteras en Vélez Blanco y redactado la memoria correspondiente para su publicación (1918), conocía la importancia de tomar notas de todo cuanto acontecía en el día a día. Por ello el trabajo de campo lo acompaña de detalladas fichas, dibujos y fotografías que suele ir tomando sobre el terreno y pasando a limpio por la noche y redactando durante los meses posteriores. Gracias a esas notas pudo reproducir las características de algunas tumbas que fueron totalmente destruidas posteriormente como bien destaca en una de sus cartas.

..la que por su tamaño y esmerada construcción su-
puse contenía un rico ajuar funerario, resultó que
después de una esmerada y larga excavación y de
haber perdido una bonita moneda que llevaba de dije
(todo se conjuró) no contenía nada en absoluto, por
lo que supongo que tanto esta sepultura como todas
las del mismo tipo que van excavadas fueron saquea-
das en tiempos antiguos, por estar muy visibles, pero
al menos no se perdió del todo el tiempo, tomé nota
del tamaño, orientación y construcción pudiendo
apreciar que el corredor de entrada estuvo pintado
de rojo, sacando las fotografías que acompaño, con
esta señal por la espalda... (Carta de Motos, 3-11-
1917. M.C.,21/274)

La potencia arqueológica del yacimiento y sus materiales le hacen pensar en su publicación casi desde el primer mes de campaña, de ahí que vaya haciendo dibujos de las tumbas que excava o revisa. La fotografía, 
además, se convirtió en una de sus mejores aliadas para documentar lo hallado, como venía sucendiendo en otras excavaciones españolas (González, 2007), y para informar a Cerralbo, si bien, como dice a menudo, no es fácil encontrar placas para hacer todas las que le hubiese gustado. Le informa igualmente de cómo está ordenando y clasificando el material para la posible publicación de la Memoria. Esta actividad de anotaciones, dibujo y primeras redacciones resulta fundamental para entender el detalle de cada una de las tumbas que luego se traslada a la Memoria. En esas fechas considera que tal publicación ha de hacerla conjuntamente con el marqués de Cerralbo. En distintas cartas, a lo largo de los meses, comenta como está trabajando y la perspectiva de elaborar la memoria:

De todo tengo notas exactas, cuya descripción le mandaré tan pronto estén en limpio como también fotografías de todo, tan pronto adquiera placas para hacerlas, que ahora resulta difícil hacerse de ellas por este país; y con estos datos y sus muchos conocimientos en esta materia y su erudición creo haremos una memoria que ha de llamar la atención. (Carta de 26 de junio de 1917. Museo Cerralbo, 21-263)

Recibí su atenta 29 del pasado alegrándome de que los trabajos hasta la fecha realizados sean de su agrado; ahora me ocupo en hacer la descripción de cada una de las sepulturas, así como también de algunos dibujos y cuando estén listos mandarlos. (Carta de 13 de julio de 1917. Museo Cerralbo, 21-257)

Me estoy ocupando en ordenar los objetos de cada una de las sepulturas que llevo encontradas con apuntes de como se encontraban, medidas, descripción de las sepulturas para tenerlo dispuesto para cuando V.E. me avise y hacer nuestra monografía. Es de interés que se analicen las sustancias que con mi hijo le remití; pueden aclarar algo hasta ahora desconocido de aquella época. (18-XI-17, M.C. 21-275)

Tenía vivos deseos de ponerle en conocimiento mis descubrimientos últimos no habiéndolo hecho antes por incluirle las fotografías que le acompaño con objeto que mejor se haga cargo de los objetos encontrados. (3 nov.1917. M.C. 21.274)

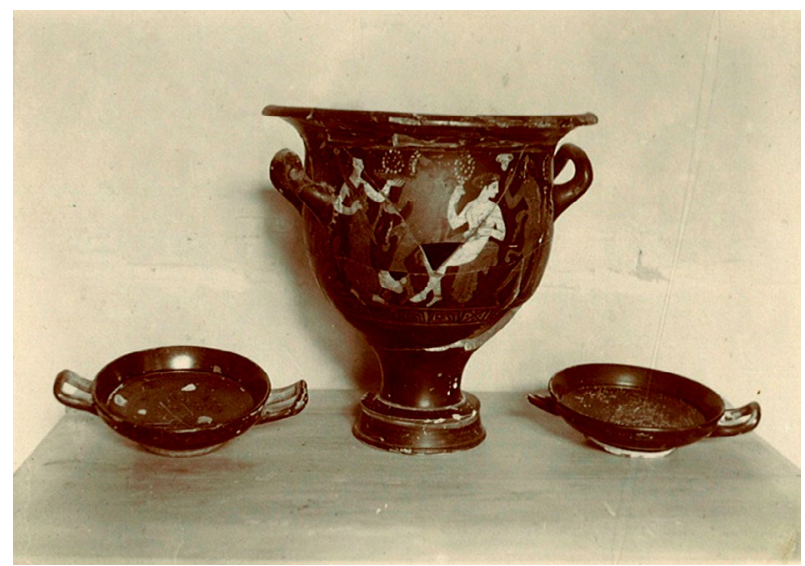

Figuras 11: Vasos griegos de Tútugi. En el reverso nota manuscrita: «vasijas griegas procedentes de sepulturas de Galera del Cerro llamado de San Gregorio». Fotografía y notas de Federico de Motos. Museo Cerralbo.
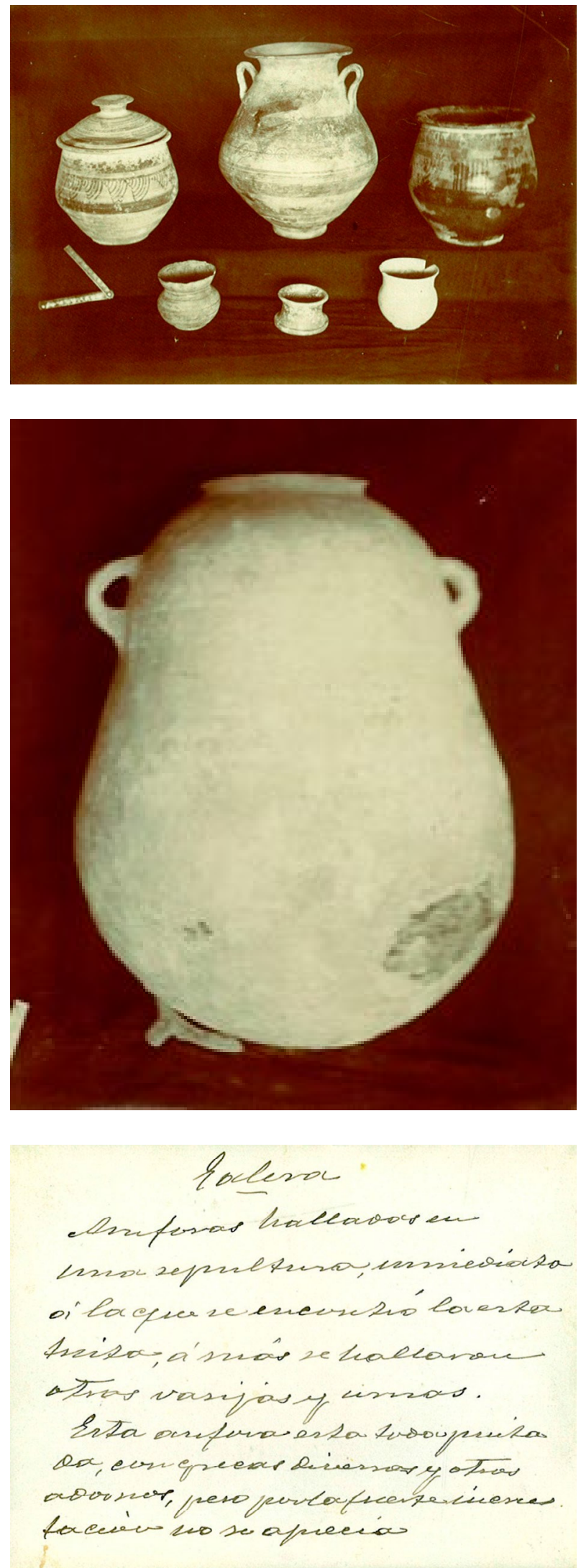

Figuras 12, 13 y 14: Vasos ibéricos. En el reverso nota manuscrita. Fotografía y notas de Federico de Motos. Museo Cerralbo.

Hace un mes que tuve el gusto de dirigirme a usted dandole cuenta de mis últimos descubrimientos 
realizados en Galera en octubre pasado, acompañandole varias fotografías de varias sepulturas...

...Remito tres fotografías que creo no incluía en mi anterior, una es de un ánfora pintada encontrada por $\mathrm{mi}$, hay dos iguales, otra es un vaso griego que encontró un labrador y se lo compré, está completamente intacto, por el otro lado tiene dos figuras con manto, y por último el otro es una bonita crátera... los platos que en la misma fotografía figuran fueron hallados por mi en otra estructura. (18-11-17. M.C. 21-275)

\section{LA NECRÓPOLIS EN LA PRENSA O EL MA- LESTAR POR EL NO RECONOCIMIENTO DE LA EXCAVACIÓN}

Las noticias sobre los descubrimientos ibéricos ocuparon un espacio en la prensa cultural especializada. La necrópolis de Galera no quedó al margen. De hecho, Mundo Gráfico incluyó un extenso reportaje sobre la cultura ibérica ilustrado con algunos objetos procedentes de la necrópolis que habían sido vendidos por las gentes del lugar y que, de este modo, veían la luz. Se trataba de la célebre Dama de Galera y una hermosa crátera griega procedente de Galera (Martínez y Muñoz, 2011; Vico, 1999). Pero no debió de gustar a Cerralbo la información aparecida. Así debió de trasladarlo a Motos preguntando por esos materiales e indicándole la necesidad de salir al paso con un artículo-informe sobre las excavaciones que oficialmente se estaban realizando. Al menos así se deduce de la carta que le envía Motos donde le da la información detallada sobre cómo habían sido vendidos dichos objetos, le adjunta una carta de Blas Tripiana, el señor que vende la estatuilla, y le informa de que está preparando un artículo para dar la información adecuada sobre la necrópolis. Por el inteŕes de la carta la reproducimos completa (M.C. 21-261).

10 de agosto de 1917

Mi respetable y distinguido amigo:

Acaba de llegar a mi poder su atenta fecha 9, la que me apresuro a contestar y ponerle al corriente de cuento ocurre con respecto a lo publicado por Mundo Gráfico.

Hace dos días que un amigo que tenía noticias de mis excavaciones de Galera me remitió la revista a que V. E se refiere, viendo, en efecto, la reproducción de la estatuita y la crátera cuya fotografía envié, y una ligera reseña de los descubrimientos. Estos objetos han sido encontrados hace bastante tiempo; la figura se encontró en el mes de diciembre anterior, en una sepultura que no pude terminar de excavar por el mal tiempo de frío y nieves, que me obligó a venirme a casa, y en mi ausencia un labrador vecino del sitio de la sepultura excavó y encontró la referida estatuita. Enterado de esto hice un nuevo viaje para adquirirla, lo cual no pude conseguir a pesar de haberle ofrecido una cantidad de importancia por ella, pues me decía que su amo le aconsejó no venderla porque aquello valía mucho; supe después que hacía gestiones para venderla en Madrid y conseguí por medios hábiles evitarlo, pero en el mes de marzo fue un señor a Galera que está al cuidado del Museo del Sr. Siret y éste se valió de procedimientos ilícitos para adquirirla, como se demuestra por la carta adjunta del individuo que tenía la figura que le ruego la conserve, pues creo que con esta prueba se puede rescatar judicialmente no habiéndolo puesto en práctica más bien por consideración al Sr. Siret. Los demás objetos de la sepultura como urnas y algunos platos los tengo.

La crátera la encontró otro a primeros del mes de abril, y coincidió que a los pocos días pasó un hombre comprador de antigüedades y la compró; me enteré y conseguí saber quien era, lo que por ello quería y me hiciera la fotografía que remití a V.E, diciéndole que se podía adquirir si le interesaba; lo demás del monumento romano lo encontraron unos jornaleros no habiendo más de notable que la pilastra con la inscripción, de cuyos hallazgos saqué fotografías y acompañando una ligera memoria mandé al padre Fidel Fita el que me dijo mandó archivar, pudiendo referirse el artículo a los demás objetos que menciona a los pendientes y cuentas de collar que di a V.E conocimiento, y que aún están en Galera.

Con respecto a lo que he dicho al Abate Breuil, no ha sido precisamente esto, pues tenía ya conocimiento de cuando estaba en esa por el mes de abril, en que si mal no recuerdo se lo dije a V.E; al menos tengo la seguridad de haberlo comunicado al amigo $\mathrm{Ca}$ bré. Lo que el Abate ha comunicado es una ligera noticia de mis trabajos últimos del mes de junio, de los que di a V.E conocimiento primero por diferentes cartas, una de ellas es de Galera a los primeros días de excavaciones.

Tengo hecho un artículo para Mundo Gráfico que pienso mandarlo; si V.E quiere conocerlo antes que se publique me avisa para mandárselo.

Veo conveniente que como individuo de la Junta de Excavaciones diera un aviso al Gobernador con el fin de evitar se vuelva a excavar.

He recibido una carta de un Sr. de Galera autorizándome para excavar en su finca; en otra le mandaré la carta. Manda a su fiel amigo q.e.s.m Federico

Carta adjunta. (Trascripción literal) (M.C. 21-258)

Galera, 5 de abril de 1917

$\mathrm{S}^{\mathrm{o}} \mathrm{D}$. Federico de Motos, Muy Señor mío y respetable amigo, respeto a los objetos antiguos que etenido que bender con mucho compromiso ha un compañero suyo a Dn Guillermo Gossé de Cuebas de Vera per que dijo que todo lo que V. compraba era para el mismo Museo de $\mathrm{D}^{\circ}$ Luis, que le daba quinientas pesetas... pero yo nunca hubiera bendido sin contar con uste porque sabe $\mathrm{V}$ que le dije que los tiestos estaban como $\mathrm{V}$ los dejo porque si hubiera echo animo de benderlo, pues antes le hubiera bendio al Sr. Trisran Cano de Madrid y otros tres hombres que ya le dije queria comprarme la figura ino quise benderla asta contar con uste. Pero D. Guillermo como no queria venderla, por eso me dijo que era los mismos, pues el bendela asido porque iba acompañado de Alcalde y su papá y D. Juan Molina su paisano de Vélez Rubio 
y lo que ellos dijeron tuve que otorgal, y sea yebado todos los objetos que lla le dije que tenia mis vecinos tiestos y todo lo que habia y sin otra cosa que decirle perdone me uste la farta y mande a su buen amigo Blas Tripiana

Federico de Motos preparó un artículo, revisado por Cerralbo, para Mundo Gráfico que no fue publicado, tal como se imaginaban que sucedería: «Recibí en tiempo oportuno su siempre grata de 23 del pasado, acompañada de las cuartillas, las que mandé al Director de prensa Gráfica, que me las devolvió acompañadas de un atento b.b.m diciéndome que por exceso de original no podía publicarlos, viendo por ello que acertó en sus profecías» (Carta 16-9-1917, M.C. 21-235).

Sí logró Motos que se publicase un amplio artículo en la revista La Alhambra de Granada (15-XI-1917) que se había hecho eco de los descubrimientos de Galera sin citar al responsable de la excavación y al patrocinador de la misma. Motos dejaba claro en su texto que contaba con la autorización oficial necesaria y con el apoyo y patrocinio de Cerralbo: «Creí cumplir con un deber de cortesía poner en antecedentes de estos hallazgos a mi distinguido amigo y sabio arqueólogo señor Marqués de Cerralbo, no tan sólo por el cargo importante que tiene en la Junta Superior de Excavaciones, cuanto por su reconocida competencia, en particular en la arqueología de esa época, por los extraordinarios descubrimientos que ha realizado, los cuales en su género son de los más notables hasta ahora hechos en España, siéndole tan satisfactorias las noticias $\mathrm{y}$ datos que le suministré que con desprendimiento y noble desinterés patrocina esta empresa»».

Sabemos por las cartas a Cerralbo que también mandó un artículo similar al periódico $\mathrm{ABC}$, aunque no conocemos su respuesta. Tal vez ese texto es el que publicó en un periódico local, El Heraldo, donde se da cumplida información de los pormenores de la excavación (Martínez y Muñoz, 2011).

\section{LA EXCAVACIÓN OFICIAL DE 1918 Y LA CODIRECCIÓN CON JUAN CABRÉ}

Su profesión y el mal tiempo obligaban a Motos volver a Vélez Blanco más a menudo de lo que hubiese deseado, como bien pone de relieve en sus cartas. Todo ello, junto al expolio que se cernía sobre el yacimiento $\mathrm{y}$ el alto coste que comportaba el volumen de trabajo de una necrópolis de esas dimensiones le llevaron renunciar a sus derechos de excavar en favor del Estado.

El 20 de febrero de 1918 enviaba una carta al Ministro de Instrucción Pública y Bellas Artes con la renuncia pues, aunque había llevado a cabo con resultados las excavaciones que se le autorizaron, comprendía «que para bien de los estudios arqueológicos e históricos sería muy conveniente el que, con los medios de que puede disponer el Estado se hiciera cargo de las mencionadas excavaciones, las que así podrían practicarse intensivamente, obteniendo brillantes resultados $\rangle^{7}$. En esa misma carta hay una frase que, de nuevo, nos recuerda su consideración hacia el patrimonio histórico para los intereses del país, cuando dice que con ello cree «prestar un señalado servicio a la cultura y a los intereses patrios».

Se le admitió la renuncia y, como es conocido, se acordó la continuidad y financiación oficial de las excavaciones nombrando una Comisión Directora de las mismas formada por Federico de Motos y Juan Cabré. Juan Cabré (Blánquez y Rodríguez, 2004) tenía una amplia y reconocida trayectoria arqueológica en ese momento, contaba con la confianza del marqués de Cerralbo y mantenía una cordial relación con Federico de Motos (Martínez y Muñoz, 2011). Para llevar a cabo la campaña de excavación se destinó una cantidad mucho más aceptable, 3000 pesetas. La campaña que realizaron entre julio y mediados de agosto de 1918 sirvió para excavar algunos túmulos y, sobre todo, para recapitular lo hecho hasta el momento y levantar el plano del yacimiento.

Juan Cabŕe y Federico de Motos se conocían desde hacía algunos años a través de Breuil y el estudio de las pinturas rupestres del sudeste peninsular. Esa relación, a pesar de las tensiones entre Breuil y Cabré, de las que también Motos da explicaciones a Cerralbo en una carta escrita en 1914 (M.C 20-24), se mantuvo en el tiempo tal como se percibe en esta correspondencia analizada. En ella Motos señala en numerosas ocasiones que le hubiese gustado que Cabré visitase la excavación, le manda recuerdos, incluso en los primeros momentos habla de que sería bueno que participase en la excavación. Sus palabras siempre son elogiosas hacia él, como también lo hace Juan Cabré en sus cartas al referirse a Motos.

Aunque se trataba de una campaña con financiación oficial, ambos directores mantienen informado a Cerralbo del avance de la misma. Suelen escribirle para comentar sus hallazgos y dificultades o para pedirle mapas topográficos con el fin de hacer el levantamiento del yacimiento. Sean de uno u otro director suelen adjuntar saludos, breves notas, etc. del otro.

Hace ocho días que me encuentro al lado de nuestro amigo Sr. Cabré haciendo trabajos en esta necrópolis ibérica, encontrándonos satisfechos hasta ahora por creer podamos hacer estudios que den alguna luz en esta región hasta el presente casi desconocida. Ahora con las faenas de recolección hay escasez de personas y trabajamos con poca gente, dentro de unos días aumentaremos el número de personas y de todo procuraremos tenerle en conocimiento (Carta de F. Motos, 13 de julio 1918, M.C. 21-313).

Hasta el presente entre el Sr. Motos y otros Sres. se han recuperado unos 10 vasos grandes griegos, gran

7. AGA. Exp Galera leg.10.143-64 Dirección General de Bellas Artes. 
lote de joyas de oro; muchas cajas pintadas y varios objetos y figuras de animales muy curiosos.

Uno de los extremos más interesantes de nuestras exploraciones ha de ser el levantamiento del plano del país determinando el sitio e intensidad así como la variedad de civilizaciones que hay reconocido por nosotros en esta región.

Para ello nos es indispensable buenos mapas pero no los hay a la venta. Si no sirviera de mucha molestia al Sr. quedaríamos altamente agradecidos, que indicara a Ricardo que se pasara por el Instituto Geográfico y Estadístico y le vendieran las hojas correspondientes a Galera, Orce y Castillejar. (Carta de inicio de julio (posible día 5) de 1918 de Juan Cabré al marqués de Cerralbo. Museo Cerralbo, 21-314)

\section{ELABORACIÓN DE LA MEMORIA}

Dado que lo que se ha conocido acerca de esta excavación figura, sobre todo, en la Memoria publicada, firmada por Cabré y Motos, parece oportuno hacer algunas consideraciones sobre la misma para deshacer algunas interpretaciones sobre la autoría de los textos que las cartas de Cabré a Motos rectifican. Utilizamos aquí las cartas de Cabré a Motos encontradas en el Archivo familiar de Motos por entender que es una buen colofón para este artículo sobre la necrópolis de Galera.

Los pormenores de la elaboración de la Memoria pueden seguirse en la correspondencia que mantuvieron Juan Cabré y Federico de Motos entre 1919 y 1920. A comienzos de diciembre de 1918 Motos viajaba a Madrid, para, entre otras cuestiones, fijar con Cabré el esquema de la Memoria y la distribución del trabajo. Éste, en una carta dirigida a Motos y, fechada en febrero de 1919, escribe:

Como me dice Usted que ha variado algo los capítulos le ruego que escriba cuanto se le ocurra respecto al conjunto de la memoria y me mande las cuartillas. Ello obedece para evitar que ambos trabajemos sobre el mismo tema y yo a la vista de lo que haya escrito añadiré o intercalaré cuanto sea necesario y luego el total se lo remitiré para su aprobación. ¿No le parece a Usted bien? (Carta de Cabré a Motos, 232-1919. Archivo Motos)

Cabré, preocupado con los plazos de entrega de la Memoria, instaba a Motos a ultimar sus notas para, a la vista de ellas, completar el estudio. Así le dice en una de sus cartas:

Esto es esencialísimo, de tal modo que no veo medio de poder yo escribir por no saber lo que ha escrito temiendo hacer una labor duplicado y otros puntos ni mencionarlos ni usted ni yo. (Carta de Cabré a Motos, 15 -3-1919. Archivo Motos)

Motos escribió buena parte de su texto inicial en los primeros meses de 1919, pues en mayo de ese año Juan Cabré ya disponía del capítulo I, la modificación

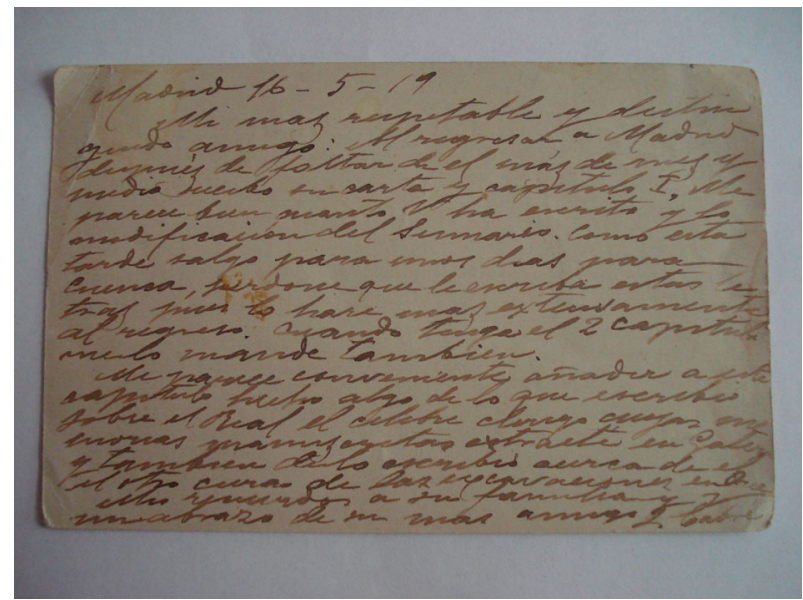

Figura 15: Carta de Juan Cabré a Federico de Motos. Archivo Motos.

del sumario propuesta por Motos, y esperaba que le llegase el capítulo II. Sin duda, la correspondencia entre ambos fue fluida y en ella fueron desgranando detalles de temas a incluir. También aluden a los dibujos y fotografías de la excavación que Motos envió para la Memoria, como el propio Juan Cabré señala en otra de sus cartas:

Escribiendo esta carta, llega el cartero con la suya en la que me remite sus dibujos. Tales dibujos vienen al pelo para insertarlos en el texto de la Memoria en su lugar correspondiente, o sea en el capítulo de la descripción de las sepulturas de la necrópoli por orden geográfico, pues si Ud. opina como yo, aparte presentaremos para la reproducción al final para que sirva de láminas sueltas las fotografías de cada una de las sepultura. (Carta de Cabré a Motos, 15-31919. Archivo Motos)

También hay referencias a un envío por parte de Motos de fotografías, que él piensa ampliar. Es lógica esta manera de trabajar, mucho más cuando, como hemos visto, Federico de Motos era bastante minucioso en las descripciones de los lugares y de los materiales ${ }^{8}$. La información ofrecida por estas cartas hace justicia con el trabajo realizado por Federico de Motos, pues ha sido corriente considerar, incluso en recientes publicaciones, que la Memoria de las excavaciones de Galera fue escrita por Cabré, dada la minuciosidad con la que describe el contexto (Martínez y Muñoz, 2011).

La Memoria veía la luz definitivamente en 1920. En su momento fue un documento relevante para el conocimiento de la cultura ibérica, particularmente de las necrópolis; y lo sigue siendo en la actualidad. Tuvo

8. Incluso estando en pruebas de imprenta la Memoria, Cabré le pide una referencia de una nota escrita por Motos sobre las tumbas de honor de Borgoña, pues si no es completa no tiene validez. Carta de 12 de junio de 1920. AM. En la citada Memoria puede verse que esta teoría la barajan ante las sepulturas que no han sido utilizadas. 
el enorme acierto de dar a conocer una importante necrópolis ibérica, pero también de mostrar las luces y las sombras que acompañaban a los descubrimientos arqueológicos en aquella España de principios del siglo XX. A lo largo del texto, como en las cartas que hemos presentado, se aprecia el esfuerzo personal, económico e intelectual de arqueólogos, paleontólogos e historiadores, ligados a las Instituciones más avanzadas de España, por rescatar y estudiar el rico patrimonio histórico del país. Pero, de igual modo, se percibe el desconocimiento, la incultura, la falta de medios para hacer las investigaciones, la pillería de algunos y la pobreza en la que se vivía en muchos campos españoles. También es buen exponente del grado de conocimiento que se tenía de la cultura ibérica y de su relación con el ámbito mediterráneo (griego, cartaginés..), o del método de trabajo seguido para hacer y comunicar los descubrimientos.

Sin duda, gracias al esfuerzo primero de Federico de Motos y, después de éste y Cabré, con el concurso de Cerralbo, podemos conocer muchas de las estructuras de las sepulturas de la necrópolis y de los ajuares que los acompañaban. Es más, tal vez gracias a su acción, algunos de ellos, como la conocida Dama de Galera, no salieron de España como antes había sucedido con la de Elche.

Los materiales que Federico de Motos consiguió en su primera excavación de 1917 pasarían a formar parte del Museo Arqueológico Nacional. En una carta de 27 de febrero de 1918 la Dirección General de Bellas Artes informaba a Motos del acuerdo de remitir a la Junta Superior de Excavaciones Arqueológicas la instancia por él elevada en la que solicitaba que fuesen adquiridos por el Estado los objetos hallados en las excavaciones de Galera y que había depositado en el Museo Arqueológico Nacional ${ }^{9}$. La Junta Superior nombró como peritos a José Ramón Mélida y al Académico de de Bellas Artes D. Narciso Sentenach, que informaron positivamente. El informe de la Real Academia también fue elaborado por Mélida y publicado en su Boletín ${ }^{10}$. Este proceso concluiría a comienzos de 1922 con la adquisición definitiva de la colección.

\section{HILANDO CONCLUSIONES}

La correspondencia se ha revelado como una fuente importantísima en la investigación histórica. Dado su carácter más personal ofrece un conjunto de informaciones sobre los acontecimientos, las vivencias cotidianas, las emociones, las expectativas de las personas implicadas que difícilmente se encuentran en otro tipo de fuentes.

9. AGA, leg.10.143-64.

10. BRAH, 77 (1920), 390-394.
En nuestro caso, las cartas de Motos a Cerralbo ofrecen una rica información sobre las circunstancias en las que se llevó a cabo la excavación de esta necrópolis y las tensiones y conflictos habidos entre los diversos agentes relacionados con ella. A través de ellas conocemos mejor cómo circulaba la información entre las personalidades implicadas e interesadas en la arqueología y qué tipo de informes les motivaban a apoyar su excavación. En nuestro caso es evidente que el marqués de Cerralbo, a la vista de los informes presentados y de los objetos que le muestra Motos, decide colaborar en su financiación, participando en un mecenazgo arqueológico que fue decisivo para el inicio de la excavación y, en consecuencia, para el estudio y conservación de una parte de su riqueza patrimonial.

Las cartas de Motos arrojan también luz sobre su figura y su obra, en una época y una zona, el sureste peninsular, que, por su lejanía de los centros neurálgicos del poder y la producción del conocimiento, podría parecer instalada en la incultura y el abandono. La historiografía española ha tardado más de lo que debiera en recuperar el significado de muchas personalidades de esta época, que, como auténticos pioneros, contribuyeron a ensanchar el conocimiento sobre el pasado histórico, a estudiar y poner en valor el rico patrimonio arqueológico de nuestro país, y que, a veces, arriesgaron trabajo, posición y patrimonio por esos ideales.

Estas cartas permiten repensar la contribución al conocimiento histórico de muchas de estas personalidades situadas en la periferia geográfica y de los centros oficiales del saber que, con sus investigaciones, nutrieron con una abundante y rica información sobre el patrimonio histórico a los Centros de Investigación españoles que iniciaban su andadura como la Comisión de Investigaciones Paleontológicas y Prehistóricas, Centro de Estudios Históricos, etc.

\section{REFERENCIAS}

Abascal Palazón, J. M. (2006). Las cartas del Marqués de Cerralbo a Adolfo Herrera y los catálogos Monumentales de España. Lucentum, XXV, 215-222. DOI: http://dx.doi. org/10.14198/LVCENTVM2006.25.12

Alvar, J. (2007). El marqués de Cerralbo, la Arqueología y el coleccionismo. En J. Beltrán Fortes, B. Cacciotti y B. Palma (Coords.). Arqueología, coleccionismo y antigüedad: España e Italia en el siglo XIX (pp. 23-36). Sevilla: Ediciones Universidad.

Aranegui Gascó, C. (2012). Los Iberos, ayer y hoy: arqueologias y culturas. Madrid: Marcial Pons.

Blánquez Pérez, J. y Rodán Gómez, L. (Eds.). (1999). La cultura Ibérica a través de la fotografía de principios de siglo. Un homenaje a la memoria. Madrid: Patrimonio Nacional. 
Blánquez Pérez, J. y Rodríguez Nuere, B. (Coord.) (2004). El arqueólogo Juan Cabré (1882-1947): la fotografía como técnica documental. Madrid: Ministerio de Cultura.

Cabré, J. y Motos, F. (1920). La necrópolis ibérica de Tútugi (Galera). Madrid: Junta Superior de Excavaciones y Antigüedades.

Díaz-Andreu García, M. (1997). Nación e internacionalización. La arqueología en España en las tres primeras décadas del siglo XX. En G. Mora y M. Díaz-Andreu (Eds.). La cristalización del pasado: génesis y desarrollo del marco institucional de la arqueología en España (pp. 403-416). Málaga: Servicio de Publicaciones de la Universidad de Málaga.

Fernández Escudero, A. (2015). El marqués de Cerralbo. Una vida entre el carlismo y la arqueología. Madrid: La Ergástula.

González Reyero, S. (2007). La fotografía en la arqueología española (1860-1960): 100 años de discurso arqueológico a través de la imagen. Madrid: Real Academia de la Historia.

González Reyero, S. (2012). Íberos: sociedades y territorios del occidente mediterráneo. Madrid: C.S.I.C.

González Reyero, S. y Rueda Galán, C. (2010). Imágenes de los iberos: comunicar sin palabras en las sociedades de la antigua Iberia. Madrid: CSIC.

Granados Ortega, M Á. (2012). Don Enrique de Aguilera y Gamboa (1845-1922), XVII marqués de Cerralbo. Museo Cerrabo, Guía Breve. Madrid: Ministerio de Educación, Cultura y Deporte.

Jiménez Sanz, C. (1996). Enrique de Aguilera y Gamboa, Marqués de Cerralbo, Revista de arqueología, 182, 52-57.

López, J. y Sala, F. (1988-1989). La necrópolis del bancal del Estanco Viejo (Minateda-Hellín, Albacete). Lucentum, VII-VIII, 133-159. DOI: http://dx.doi.org/10.14198/ LVCENTVM1988-1989.7-8.06

Martínez López, C. (2016). Federico de Motos (1865-1931). La pasión por la arqueología. Revista Velezana, 34, 175-187.

Martínez López, C. y Muñoz, F. A. (2011). Federico de Motos. Historia y arqueología del sureste peninsular en los inicios del siglo $X X$. Granada: Editorial Universidad.

Moret, P. (1998). Pierre Paris, precursor de la arqueología ibérica. En Los íberos. Príncipes de Occidente (pp. 70-71). Barcelona: Fundación La Caixa.
Motos, F. (1917). De arqueología regional. Un interesante descubrimiento en Granada. Heraldo de los Vélez, 13, 3.

Motos, F. (1917). Descubrimientos de Galera. La Alhambra. Revista quincenal de Artes y Letras, 471, 483-486.

Motos, F. (1918). La edad neolítica en Vélez Blanco. Madrid: Museo Nacional de Ciencias Naturales.

Navascués, P., Conde, C. y Jiménez, C. (1998). El marqués de Cerralbo. Madrid: Ministerio de Cultura.

Olmos, R. (1998). La invención de la cultura ibérica. En Los íberos. Príncipes de Occidente (pp. 59-65). Barcelona: Fundación La Caixa.

Pereira, J., Chapa, T., Madrigal, A., Uriarte, A., y Mayoral, V. (2004). La necrópolis ibérica de Galera (Granada). La colección del museo arqueológico nacional. Madrid: Ministerio de Cultura.

Ramos Fernández, R. (2003). Documentos y reflexiones sobre una dama. Elche: Ayuntamiento de Elche.

Rodríguez Ariza, M.O. (2008). Tútugi. Nuevos trabajos. En A. Adroher y J. Blánquez (Eds.). ler Congreso Internacional de Arqueología Ibérica Bastetana / 1, 317-334.

Rodríguez Ariza, M ${ }^{\mathrm{a}}$ O. (2014). La necrópolis ibérica de Tútugi (2000-2012). Jaén: Publicaciones Universidad.

Rodríguez Ariza, M ${ }^{\mathrm{a}}$ O. et al. (2008). El túmulo 20 de la necrópolis Ibérica de Tútugi (Galera, Granada). Trabajos de prehistoria, 65(1), 169-180. DOI: http://dx.doi.org/10.3989/ tp.2008.v65.i1.142

Ruiz, A. y Molinos, M. (2003). Los iberos: análisis arqueológico de un proceso histórico. Madrid: Crítica.

Ruíz, A., Bellón, J.A. y Sánchez, A. (Coords.). (2006). Los archivos de la arqueología ibérica: una arqueología para dos Españas. Jaén: Universidad de Jaén.

Tortosa Rocamora, T. y Olmos Romera, R. (Coords.). (1997). La Dama de Elche. Lecturas desde la diversidad. Madrid: Asociación científica Lynx.

Varela Hervías, E. (1918). Cerámica ibérica de El Tolmo de Minateda (Albacete). Revista de Archivos, bibliotecas y museos, XII, 382-391.

Vico Belmonte, A. (1999). Las excavaciones en Galera y la prensa granadina de la época (1900-1935). En J. Blánquez y L. Roldán (Eds.). La cultura ibérica a través de la fotografía de principios de siglo. Madrid: Patrimonio Nacional. 